\title{
KONTRIBUSI DARI RETRIBUSI IZIN PELAYANAN PEMAKAMAN TERHADAP PENDAPATAN ASLI DAERAH KOTA PALEMBANG TAHUN 2015-2019
}

\author{
Kemas Welly Angga Permana \\ Program Studi Ekonomi Akuntansi, Universitas Sjakhyakirti, Palembang \\ E-mail : kemaswelly@unisti.ac.id
}

\begin{abstract}
ABSTRACK
The era of decentralization and regional autonomy is a challenge for every region to take advantage of opportunities in exploring regional potential. Efforts to increase local revenue $(P A D)$ can be done by increasing the effectiveness of receiving retribution from PAD sources, especially local fees. This study aims to determine and analyze the contribution of funeral service permit fees to the local revenue of Palembang City in 2015-2019. The collection of user fees has been regulated in Regional Regulation Number 12 of 2015 concerning charges for funeral services and asylum which is a basic reference for maximizing administrative services managed by Ilir Barat Satu Sub-district, Palembang City. This research uses descriptive quantitative analysis method. The data collection technique is done by using secondary data through documentation techniques. The data used is a funeral service permit retribution. The analysis method used is contribution analysis, which is an analytical tool used to determine how much the contribution of levies is to local revenue. The result of the research is that the contribution value of funeral service permit fees shows a tendency to fluctuate each year. The average percentage contribution of receiving funeral service permit fees with good enough criteria reaches $20.17 \%$ which means it contributes to the Regional Original Income of Palembang city.
\end{abstract}

Keywords : Competence, Supervision, Work Productivity

\begin{abstract}
ABSTRAK
Era desentralisasi dan otonomi daerah menjadi tantangan bagi setiap daerah untuk memanfaatkan peluang dalam menggali potensi daerah. Upaya peningkatan pendapatan asli daerah (PAD) dapat dilakukan dengan meningkatkan efektivitas penerimaan retribusi dari sumber PAD khususnya retribusi daerah. Penelitian ini bertujuan untuk mengetahui dan menganalisis kontribusi retribusi izin pelayanan pemakaman terhadap penerimaan pendapatan asli daerah Kota Palembang tahun 2015-2019. Pemungutan retribusi telah diatur dalam Peraturan Daerah Nomor 12 Tahun 2015 tentang retribusi pelayanan pemakaman dan pengabuan mayat yang merupakan acuan dasar untuk memaksimalkan pelayanan administratif yang dikelola oleh Kecamatan Ilir Barat Satu Kota Palembang. Penelitian ini menggunakan metode analisis deskriptif kuantitatif. Teknik pengumpulan data dilakukan dengan menggunakan data sekunder melalui teknik dokumentasi. Data yang digunakan adalah retribusi izin pelayanan pemakaman. Metode Analisis yang di gunakan yaitu analisis kontribusi, yaitu suatu alat analisis yang digunakan untuk mengetahui seberapa besar kontribusi retribusi terhadap pendapatan asli daerah. Hasil penelitian adalah nilai kontribusi penerimaan retribusi izin pelayanan pemakaman menunjukkan adanya kecenderungan berfluktuasi tiap tahunnya presentase rata- rata kontribusi penerimaan retribusi izin pelayanan pemakaman dengan kriteria cukup baik mencapai 20,17\% artinya memberikan kontribusi terhadap Pendapatan Asli Daerah kota Palembang.
\end{abstract}

Kata kunci : Kontribusi, Retribusi, Pendapatan Daerah 


\section{PENDAHULUAN}

$\begin{array}{cll}\text { Dalam } & \text { kerangka } & \text { sistem } \\ \text { penyelenggaraan } & \text { pemerintah } & \text { sistem }\end{array}$ pengelolaan keuangan daerah. Keuangan daerah merupakan semua hak dan kewajiban dalam rangka penyelenggaraan pemerintah daerah yang dapat dinilai dengan uang termasuk didalamnya segala bentuk kekayaan lain yang berhubungan dengan hak dan kewajiban daerah tersebut dalam kerangka APBD. APBD merupakan suatu rencana keuangan tahunan daerah yang ditetapkan berdasarkan peraturan pemerintah tentang APBD. Undang-undang No 22 Tahun 1999 tentang Pemerintahan Daerah adalah salah satu landasan yuridis bagi pengembangan otonomi daerah di Indonesia. Dalam undang-undang ini disebutkan bahwa pengembangan otonomi pada daerah Kabupaten dan Kota diselenggarakan dengan memperhatikan prinsip-prinsip demokrasi, peran serta masyarakat, pemerataan dan keadilan, serta memperhatikan potensi dan keanekaragaman daerah. Otonomi yang diberikan kepada daerah Kabupaten dan Kota dilaksanakan dengan memberikan kewenangan yang luas, nyata dan bertanggungjawab kepada pemerintah daerah secara proporsional. Artinya, pelimpahan tanggungjawab akan diikuti oleh pengaturan pembagian, dan pemanfaatan dan sumber daya nasional yang berkeadilan, serta perimbangan keuangan pusat dan daerah.

Dalam hal ini pemerintah daerah selalu berupaya meningkatkan pendapatan daerah dari tahun ke tahun yang merupakan program yang mutlak dilaksanakan oleh seluruh jajaran pemerintah daerah yang terkait dengan penerimaan atau pendapatan daerah. Retribusi daerah merupakan salah satu sumber pendapatan daerah yang diharapkan dapat membantu pembiayaan daerah untuk melaksanakan otonomi sendiri. Kemampuan retribusi daerah yang dimiliki setiap daerah merupakan salah satu indikator kesiapan pemerintah daerah yang berotonomi daerah. Oleh karena itu, perolehan retribusi daerah disarankan meningkatkan pendapatan asli daerah yang digunakan untuk menyelenggarakan otonomi daerah yang secara konseptual diharapkan memiliki kemampuan nyata dan bertanggung jawab.

Penetapan jenis retribusi ke dalam retribusi jasa umum dan jasa usaha dibuat dengan peraturan pemerintah agar tercipta ketertiban dalam penerapannya sehingga dapat memberikan kepastian pada masyarakat serta dapat disesuaikan dengan kebutuhan di daerah yang bersangkutan. Demikian pula untuk beberapa jenis perizinan tertentu juga ditetapkan dengan peraturan pemerintah karena perizinan tersebut merupakan kewenangan pemerintah daerah. Retribusi daerah adalah pungutan daerah sebagai pembayaran jasa atau pemberian izin tertentu yang khusus disediakan dan atau diberikan oleh pemerintah daerah untuk kepentingan orang pribadi maupun badan.

Pada masing-masing kelompok retribusi daerah, terdiri atas berbagai macam retribusi yang jenisnya sangat banyak dan beragam. Pada kesempatan kali ini penulis akan memfokuskan pada retribusi izin pelayanan pemakaman di kota Palembang termasuk dalam kelompok retribusi perijinan tertentu. Dari tahun ke tahun terdapat kesenjangan penerimaan yang cukup signifikan. Hal itu dapat terlihat dari laporan penerimaan pemerintah kota Palembang 2015 sampai 2019. Seperti yang kita ketahui bahwa kota Palembang merupakan salah satu kota yang mampu menggali potensi daerahnya sendiri. Salah satu potensi yang dimiliki adalah pendapatan retribusi izin pelayanan pemakaman.

Upaya yang dilakukan untuk mengembangkan dan membangun daerah dalam meningkatkan sumber-sumber pendapatan asli daerah sesuai potensi yang dimiliki agar peningkatan target setiap tahunnya dapat diikuti dengan pencapaian realisasi secara konsisten salah satu 
kebijakan pemerintah daerah di Kota Palembang mengeluarkan kebijakan berupa peraturan daerah nomor 12 tahun 2015 tentang retribusi pelayanan pemakaman dan pengabuan mayat. Maksud dan tujuan peraturan daerah yaitu:

1. Pemerintah daerah bermaksud mengatur dan mengendalikan pemakaian tempat pemakaman serta pelayanan pemakaman dan atau pengabuan;

2. Pengaturan dan pengendalian tempat pemakaman serta pelayanan pemakaman dan atau pengabuan mayat bertujuan untuk menjaga ketertiban pengadaan lahan pemakaman, mengatur penataan tempat pemakaman agar tertata rapi dan indah selaras dengan Rencana Tata Ruang \& Pembangunan Palembang;

3. Untuk meningkatkan penerimaan daerah guna menunjang pelaksanaan pembangunan penyelenggaraan pemakaman \& pelayanan kepada masyarakat.

Di kota Palembang terdapat 17 (tujuh belas) TPU dan telah menetapkan retribusi pemakaman yang masuk PAD untuk muslim sebesar Rp.50.000,- (lima puluh ribu) dan non muslim sebesar Rp.100.000,- (seratus ribu). Jarak antar pemakaman telah diatur yakni $50 \mathrm{~cm}$ dengan makam lain dengan tinggi hanya $10 \mathrm{~cm}$ dari gundukan tanah. Taman pemakaman umum (TPU) yang terdapat pada wilayah Kecamatan Ilir Barat Satu Kota Palembang sendiri cukup banyak yang dimiliki masyarakat, swasta dan pemerintahan. Dari sekian banyak pemakaman yang tersebar hanya dua TPU yang dikelola oleh pemerintah kota Palembang yaitu TPU puncak sekuning dan TPU bukit lama. Salah satu taman pemakaman umum di wilayah Kecamatan Ilir Barat Satu yaitu TPU puncak sekuning yang berada di kelurahan lorok pakjo sudah tidak layak lagi untuk dijadikan tempat pemakaman jenazah mengingat lahan tersebut semakin sempit sudah over kapasitas, alasannya warga setempat hampir seragam agar tidak jauh dari keluarga atau rumah tempat tinggal mereka. Sedangakan TPU bukit lama yang berada di kelurahan bukit lama kondisi lahannya masih cukup luas. Dilihat dari lokasi TPU mayoritas warga muslim maka kebanyakan hanya melakukan 2 (dua) jenis pemberkasan izin pemakaman yaitu izin pemakaman baru untuk masa berlaku 3 (tiga) tahun dan izin perpanjangan pemakaman setelah masa berlaku habis. Jika masa perpanjangan izin tidak dilakukan maka pihak TPU akan mengkonfirmasi kepada pihak ahli waris terlebih dahulu, tidak langsung ditimpah. Menurut para ulama, satu makam bisa digabungkan dengan makam baru dengan syarat makam lama tersebut sudah lebih dari 10 (sepuluh) tahun.

Pungutan retribusi berdasarkan peraturan daerah kota Palembang nomor 12 tahun 2015 dipungut dengan menggunakan surat ketetapan retribusi daerah atau dokumen lain yang dipersamakan. Dalam hal wajib retribusi tidak membayar tepat pada waktunya atau kurang membayar, dikenakan sanksi administrasi berupa bunga sebesar $2 \%$ (dua persen) setiap bulan dari dari retribusi yang terutang yang tidak atau kurang bayar dan ditagih dengan mengunakan surat ketetapan retribusi daerah (SKRD) yang diprint out di Kecamatan Ilir Barat Satu.

Hal ini guna untuk merawat dan memelihara pemakaman dengan penghijauan seperti taman kota. Serta meningkatkan pendapatan asli daerah meskipun targetnya sangat kecil. Setiap tahun jumlah kematian yang terjadi di kota Palembang bertambah banyak, tetapi pertambahan ini tidak di imbangi dengan persediaan tanah di kota Palembang itu sendiri. Hal ini dikarenakan perkembangan pembangunan di kota Palembang yang berkembang pesat. 


\section{Tabel 1}

Daftar Taman Pemakaman umum (TPU) kota Palembang

\begin{tabular}{|c|c|c|c|}
\hline No. & Nama TPU & $\begin{array}{l}\text { Jenis } \\
\text { TPU }\end{array}$ & Kecamatan \\
\hline 1. & TPU bukit lama & Muslim & $\begin{array}{l}\text { Kecamatan ilit barat } \\
\text { satu }\end{array}$ \\
\hline 2. & $\begin{array}{l}\text { TPU puncak } \\
\text { sekuning }\end{array}$ & Muslim & $\begin{array}{l}\text { Kecamatan ilit barat } \\
\text { satu }\end{array}$ \\
\hline 3. & TPU kamboja & Muslim & $\begin{array}{l}\text { Kecamatan ilit } \\
\text { timur satu }\end{array}$ \\
\hline 4. & $\begin{array}{l}\text { TPU kandang } \\
\text { kawat }\end{array}$ & Muslim & $\begin{array}{l}\text { Kecamatan ilit } \\
\text { timur dua }\end{array}$ \\
\hline 5 . & TPU sei goren & Muslim & $\begin{array}{l}\text { Kecamatan } \\
\text { seberang ulu satu }\end{array}$ \\
\hline 6. & $\begin{array}{l}\text { TPU naga } \\
\text { swidak }\end{array}$ & Muslim & $\begin{array}{l}\text { Kecamatan } \\
\text { seberang ulu dua }\end{array}$ \\
\hline 7. & TPU sako & Muslim & Kecamatan sako \\
\hline 8. & $\begin{array}{l}\text { TPU talang } \\
\text { kerikil }\end{array}$ & Muslim & $\begin{array}{l}\text { Kecamatan } \\
\text { kemuning }\end{array}$ \\
\hline 9. & TPU kalidoni & Muslim & Kecamatan kalidoni \\
\hline 10. & TPU sei selayur & Muslim & Kecamatan kalidoni \\
\hline 11. & TPU gandus & Muslim & Kecamatan gandus \\
\hline 12. & $\begin{array}{l}\text { TPU kebun } \\
\text { bunga }\end{array}$ & Muslim & $\begin{array}{l}\text { Kecamatan } \\
\text { sukarami }\end{array}$ \\
\hline 13. & $\begin{array}{l}\text { TPU talang } \\
\text { jambe }\end{array}$ & $\begin{array}{c}\text { Non } \\
\text { muslim }\end{array}$ & $\begin{array}{l}\text { Kecamatan } \\
\text { sukarami }\end{array}$ \\
\hline 14. & $\begin{array}{l}\text { TPU talang } \\
\text { kerikil }\end{array}$ & $\begin{array}{c}\text { Non } \\
\text { muslim }\end{array}$ & $\begin{array}{l}\text { Kecamatan } \\
\text { sukarami }\end{array}$ \\
\hline 15. & $\begin{array}{l}\text { TPU talang } \\
\text { petai }\end{array}$ & Muslim & Kecamatan plaju \\
\hline 16. & TPU keramasan & Muslim & $\begin{array}{l}\text { Kecamatan } \\
\text { kertapati }\end{array}$ \\
\hline 17. & $\begin{array}{l}\text { TPU talang } \\
\text { kelapa }\end{array}$ & Muslim & $\begin{array}{l}\text { Kecamatan alang- } \\
\text { alang lebar }\end{array}$ \\
\hline
\end{tabular}

Sumber : Data Taman Pemakaman Umum (TPU) Kota Palembang, 2019

Tabel 2

\section{Jumlah penerimaan retribusi izin} pelayanan pemakaman

\begin{tabular}{|c|c|c|c|c|c|c|}
\hline \multirow{7}{*}{ Tahun } & \multicolumn{7}{|c|}{ Realisasi Retribusi Izin Pemakaman } \\
\cline { 2 - 8 } & $\begin{array}{c}\text { Kelurahan } \\
\text { Bukit } \\
\text { Baru }\end{array}$ & $\begin{array}{c}\text { Kelurahan } \\
\text { Bukit Lama }\end{array}$ & $\begin{array}{c}\text { Kelurahan } \\
\text { Siring } \\
\text { Agung }\end{array}$ & $\begin{array}{c}\text { Kelurahan Lorok } \\
\text { Pakjo }\end{array}$ & $\begin{array}{c}\text { Kelurahan } \\
\text { Demang } \\
\text { LD }\end{array}$ & $\begin{array}{c}\text { Kelurahan 26 } \\
\text { Ilir D 1 }\end{array}$ \\
\cline { 2 - 8 } & $\begin{array}{c}\text { Tidak } \\
\text { ada } \\
\text { TPU }\end{array}$ & TPU Bukit Lama & $\begin{array}{c}\text { Tidak ada } \\
\text { TPU }\end{array}$ & $\begin{array}{c}\text { TPU Puncak } \\
\text { Sekuning }\end{array}$ & $\begin{array}{c}\text { Tidak } \\
\text { ada } \\
\text { TPU }\end{array}$ & $\begin{array}{c}\text { Tidak ada } \\
\text { TPU }\end{array}$ \\
\hline 2015 & - & Rp.7.975.000,- & - & Rp.10.525.000,- & - & - \\
\hline 2016 & - & Rp.9.925.000,- & - & Rp.15.375.000,- & - & - \\
\hline 2017 & - & Rp. 10.950.000,- & - & Rp. 19.250.000,- & - & - \\
\hline 2018 & - & Rp. 16.675.000,- & - & Rp.27.200.000,- & - & - \\
\hline 2019 & - & Rp.17.700.000,- & - & Rp.32.075.000,- & - & - \\
\hline
\end{tabular}

Sumber : Data Kecamatan Ilir Barat Satu Kota Palembang, 2019
Pada tabel di atas dapat dilihat bahwa efektivitas retribusi izin pelayanan pemakaman pada wilayah Kecamatan Ilir Barat Satu kota Palembang periode 20152019 setiap tahunnya mengalami perubahan. Dengan melihat rata-rata efektivitas retribusi lebih dari $100 \%$ atau rata-rata sebesar $84.60 \%$ hal ini menunjukan bahwa kinerja dalam pemungutan retribusi cukup baik.

Tabel 3

Efektifitas retribusi izin pelayanan pemakaman terhadap pendapatan asli daerah

\begin{tabular}{|c|c|c|c|c|}
\hline Tahun & $\begin{array}{l}\text { Target (PAD) } \\
\text { Retribusi Izin } \\
\text { Pemakaman }\end{array}$ & $\begin{array}{c}\text { Realisasi } \\
\text { Retribusi (PAD) } \\
\text { Izin Pemakaman }\end{array}$ & $\begin{array}{c}\text { Efektifitas } \\
\%\end{array}$ & Kriteria \\
\hline 2015 & Rp.175.000.000,- & Rp.175.950.000,- & $100,54 \%$ & $\begin{array}{l}\text { Sangat } \\
\text { efektif }\end{array}$ \\
\hline 2016 & Rp.175.000.000,- & Rp.175.875.000,- & $100,50 \%$ & $\begin{array}{l}\text { Sangat } \\
\text { efektif }\end{array}$ \\
\hline 2017 & Rp.175.000.000,- & Rp.175.425.000,- & $100,24 \%$ & $\begin{array}{l}\text { Sangat } \\
\text { efektif }\end{array}$ \\
\hline 2018 & Rp.175.000.000,- & Rp.160.325.000,- & $91,61 \%$ & Efektif \\
\hline 2019 & Rp.175.000.000,- & Rp.158.450.000,- & $90,54 \%$ & Efektif \\
\hline \multicolumn{3}{|c|}{ Rata-rata } & $96,68 \%$ & Efektif \\
\hline
\end{tabular}

Sumber : Dinas Perumahan Rakyat Kawasan Pemukiman Palembang, 2019

Pada tabel di atas dapat dilihat bahwa efektivitas retribusi izin pelayanan pemakaman terhadap pendapatan asli daerah kota Palembang setiap tahunnya mengalami perubahan. Dengan melihat rata-rata efektivitas retribusi lebih dari $100 \%$ atau rata-rata sebesar $96.68 \%$ hal ini menunjukan bahwa kinerja dalam pemungutan retribusi kota Palembang baik.

\section{Tabel 4}

Kontribusi penerimaan retribusi izin pelayanan pemakaman khususnya pada wilayah Kecamatan Ilir Barat Satu.

\begin{tabular}{|c|c|c|c|c|}
\hline \multirow{2}{*}{ Tahun } & $\begin{array}{c}\text { Realisasi } \\
\text { Retribusi Izin } \\
\text { Pemakaman } \\
\text { Di Kec IB 1 }\end{array}$ & $\begin{array}{c}\text { Realisasi } \\
\text { Retribusi (PAD) } \\
\text { Izin Pemakaman }\end{array}$ & $\begin{array}{c}\text { Kontribusi } \\
\%\end{array}$ & Kriteria \\
\hline 2015 & Rp. 18.500.000,- & Rp.175.950.000,- & $10,51 \%$ & Kurang \\
& & & & \\
\hline
\end{tabular}




\section{Jurnal Interprof}

\begin{tabular}{|c|c|c|c|c|}
\hline 2016 & Rp. 25.300.000,- & Rp.175.875.000,- & $14,38 \%$ & Kurang \\
\hline 2017 & Rp. 30.200.000,- & Rp.175.425.000,- & $17,21 \%$ & $\begin{array}{c}\text { Cukup } \\
\text { Baik }\end{array}$ \\
\hline 2018 & Rp. 43.875.000,- & Rp.160.325.000,- & $27,37 \%$ & Sedang \\
\hline 2019 & Rp. 49.775.000,- & Rp.158.450.000,- & $31,41 \%$ & Baik \\
\hline \multicolumn{3}{|c|}{ Rata-rata } & $20,17 \%$ & $\begin{array}{c}\text { Cukup } \\
\text { Baik }\end{array}$ \\
\hline
\end{tabular}

Sumber: Dinas Perumahan Rakyat Kawasan

Pemukiman Palembang, 2019

Hasil perhitungan diatas kontribusi penerimaan retribusi retribusi izin pelayanan pemakaman khususnya pada wilayah Kecamatan Ilir Barat Satu terhadap pendapatan asli daerah kota Palembang periode 2015-2019 mengalami perkembangan dari tahun ke tahun. Jika dilihat dari hasil presentase maka rata-rata kontribusi penerimaan retribusi daerah cukup baik hanya mencapai $20,17 \%$.

Berdasarkan kondisi tersebut jelas terlihat bahwa adanya standar pelayanan yang belum dilaksanakan secara maksimal berdasarkan peraturan daerah nomor 12 tahun 2015 tentang retribusi pelayanan pemakaman dan pengabuan mayat. Pemerintah harus bijak dalam mengelola retribusi daerah seperti pendapatan yang berasal dari retribusi. Pentingnya sosialisasi dari pemerintah daerah dalam memberikan informasi dan pemahaman seluas - luasnya tentang retribusi maupun sumber pendapatan asli daerah lainnya demi kesejahteraan masyarakat dan peningkatan pembangunan daerah. Serta diperlukan transparasi anggaran untuk meningkatkan kepercayaan masyarakat kepada pemerintah daerah yang bersangkutan sehingga penerimaan daerah dari retribusi pelayanan pemakaman dapat terealisasi secara optimal tiap tahunnya. Maka dari itu terkait Dinas Perumahan Rakyat dan Kawasan Permukiman kota Palembang selaku pengelola TPU harus terus meningkatkan pelayanan pemakaman dan pengabuan mayat kepada masyarakat dengan cara memperbaiki dan menambah fasilitas-fasilitas pelayanan pemakaman dan menambah tanah makam di
Vol. 6, No. 2 Desember 2020

p-ISSN : 2527-7243, e-ISSN : 2721-6772

kecamatan yang belum ada TPU milik pemerintah. Serta meningkatakan kualitas pelayanan administrasi terpadu kecamatan (PATEN) yang wewenangnya telah dilimpahkan pada Kecamatan Ilir Barat Satu kota Palembang dapat lebih baik.

\section{TINJAUAN PUSTAKA}

\subsection{Kontribusi}

Secara umum masyarakat mengartikan kontribusi sebagai sumbangsih atau peran, atau keikutsertaan seseorang dalam suatu kegiatan tertentu. Bentuk kontribusi yang bisa diberikan oleh masyarakat harus sesuai dengan kapasitas atau kemampuan masing-masing orang tersebut. Individu atau kelompok bisa menyumbangkan pikirannya, tenaganya, dan materinya demi mengsukseskan kegiatan yang direncanakan demi untuk mencapai tujuan bersama.

Menurut "kamus "Besar Bahasa Indonesia $(2003 ; 854)$ kontribusi adalah uang "iuran sumbangan (kepada perkumpulan dan sebagainya). Jadi setiap orang dapat "dikatakan berkontribusi apabila terlibat "atau melibatkan diri pada suatu kegiatan baik dalam posisinya sebagai tim kerja maupun karena jabatan yang diembannya selaku individu.

\subsection{Retribusi}

Menurut Mardiasmo (2002;100), retribusi adalah pungutan daerah sebagai pembayaran atas jasa atau pemberian izin tertentu yang khusus disediakan dan/atau diberikan oleh Pemerintah Daerah untuk kepentingan orang pribadi atau badan. Menurut Marihot P. Siahaan (2005;5), Retribusi adalah pembayaran wajib dari penduduk kepada Negara karena adanya jasa tertentu yang diberikan oleh negara bagi penduduknya secara perorangan.

\subsection{Retribusi Daerah}

Retribusi daerah adalah pungutan sebagai pembayaran atas jasa atau pemberian 
izin tertentu yang khusus disediakan dan atau diberikan oleh pemerintah daerah untuk kepentingan orang pribadi atau badan.

$$
\text { Menurut Marihot P. Siahaan }
$$

(2005;6), Retribusi Daerah adalah pungutan daerah sebagai pembayaran atas jasa atau pemberian izin tertentu yang khusus disediakan dan atau diberikan oleh pemerintah daerah untuk kepentingan orang pribadi atau badan.

\subsection{Pendapatan Asli "Daerah (PAD)"}

Pendapatan Asli Daerah (PAD) adalah penerimaan yang diperoleh daerah dari sumber-sumber dalam wilayahnya sendiri yang dipungut berdasarkan peraturan daerah sesuai dengan peraturan perundangundangan yang berlaku. Menurut Marihot P. Siahaan (2005:14), Pendapatan Asli Daerah (PAD) yaitu pendapatan yang diperoleh daerah dan dipungut berdasarkan peraturan daerah sesuai dengan peraturan perundangundangan. Menurut Mardiasmo (2002:146), Pendapatan Asli Daerah (PAD) adalah Pendapatan Asli Daerah (PAD) adalah penerimaan hasil dari setoranpajak daerah, retribusi daerah hasil dari milik daerah, hasil pengelolaan kekayaan daerah yang dipisahkan dan lain-lain pendapatan asli daerah yang sah. Sebagaimana disebutkan bahwa pendapatan asli daerah merupakan penerimaan daerah yang berasal dari berbagai sumber ekonomi asli daerah, maka diharapkan setiap pemerintah daerah dapat membangun infrastruktur ekonomi baik didaerahnya masing-masing guna meningkatkan pendapatannya.

\subsection{Tinjauan Kebijakan Pelayanan Administrasi Terpadu Kecamatan (PATEN)}

Penyelenggaraan pelayanan kepada masyarakat merupakan fungsi yang harus diemban pemerintah dalam rangka mewujudkan kesejahteraan, sebagai tolok ukur terselenggaranya tata kelola pemerintahan yang baik (good governance).
Pintu masuk (entry point) bagi percepatan reformasi birokrasi di daerah dalam mewujudkan tata kelola pemerintahan daerah yang baik (good local governance) terfokus pada peningkatan kualitas penyelenggaraan pelayanan publik. Kualitas penyelenggaraan pelayanan umum (publik) di daerah masih perlu ditingkatkan ke arah yang lebih baik.

Banyak hal yang menyebabkan belum optimalnya penyelenggaraan pelayanan tersebut, misalnya terbatasnya sarana pelayanan, perilaku petugas yang belum bersifat melayani, tidak jelasnya waktu, dan biaya yang diperlukan untuk mendapatkan pelayanan publik, serta panjangnya prosedur yang harus dilalui untuk menyelesaikan suatu jenis pelayanan publik. Oleh karenanya, daerah diharapkan terus memiliki prakarsa dalam melakukan perbaikan pelayanan. Prakarsa daerah dalam meningkatkan pelayanan publik tentunya harus sesuai kebutuhan dan sesuai dengan kepuasan masyarakat. Masyarakat berhak memberikan masukan, koreksi dan perbaikan terhadap pelayanan. Inilah yang disebut manajemen publik masa kini (new public management) yang memiliki ciri bahwa kewenangan berada pada petugas pelayanan dan pelanggan; menekankan pada pelayanan yang "menyentuh hati" dan perombakan visi dan misi pelayanan. Selanjutnya konsep itu berkembang menjadi pelayanan publik masa kini (new public service) yang memiliki ciri bahwa masyarakat dianggap sebagai pemilik saham (shareholder), sehingga pelayanan lebih menekankan pada kualitas sebagai hasil negosiasi kepentingan masyarakat dan pemerintah. Peran pemerintah adalah pelayan sekaligus perantara kepentingan beberapa kelompok masyarakat. Dengan kata lain, posisi pemerintah sebagai penyelenggara pelayanan publik berubah dari "dilayani" menjadi "melayani". Perubahan paradigma pemerintahan dari sentralisasi menuju desentralisasi pada hakekatnya harus diikuti dengan perubahan konsep penyelenggaraan pelayanan publik 
yang lebih meyakinkan akan terciptanya akses dan mutu pelayanan.

Sejalan dengan era otonomi daerah, maka pelayanan yang lebih didekatkan kepada masyarakat dan pelayanan yang lebih berkualitas adalah sebuah keniscayaan untuk mencapai kesejahteraan masyarakat. Peningkatan pelayanan publik di daerah dapat dilakukan dengan inovasi manajemen pada unit layanan di Satuan Kerja Perangkat Daerah (SKPD) atau pada tingkat yang secara langsung berhadapan dengan masyarakat yaitu kecamatan. Melakukan optimalisasi peran kecamatan dalam pelayanan merupakan jawaban atas pentingnya akses dan mutu. Hal ini lebih terlihat kepada kondisi dan situasi lingkungan strategis kecamatan, yang secara nyata terlihat pada kondisi wilayah yang letak geografisnya sulit dijangkau terutama karena berada di daerah terpencil, kepulauan, dan daerah perbatasan antar negara. Selain itu, kecamatan yang berada wilayah kabupaten memiliki rentang kendali yang amat beragam karena kendala luas wilayah, infrastruktur pembangunan kecamatan dan transportasi yang belum menjangkau dengan merata. Oleh karenanya banyak alasan mengapa kecamatan membutuhkan sentuhan atau dengan kata lain perlu ditingkatkan kapasitasnya dalam meningkatkan pelayanan kepada masyarakat. Optimalisasi peran kecamatan merupakan keniscayaan yang dapat menjadi akselerator (percepatan) dalam peningkatan pelayanan publik di daerah. Momentum ini sejalan dengan perubahan posisi kecamatan. Bila sebelumnya, kecamatan merupakan wilayah kekuasaan camat menurut Undang-Undang Nomor 5 Tahun 1974 tentang Pokok-Pokok Pemerintahan di Daerah, kini berubah menjadi wilayah kerja menurut UndangUndang Nomor 22 Tahun 1999 yang diperbaharui dengan Undang-Undang Nomor 32 Tahun 2004 tentang Pemerintahan Daerah. Wilayah kekuasaan menunjukkan adanya yurisdiksi kewenangan di dalamnya, sedangkan wilayah kerja lebih merupakan wilayah pelayanan kepada masyarakat.

\subsection{PenelitianTerdahulu}

Penelitian ini mengacu pada penelitian terdahulu yang ditulis mengenai dibawah ini :

1. Gozzali Ar Rozzaq (2010) dengan judul Kontribusi dan Efektifitas Retribusi Jasa Umum Terhadap Penerimaan Pendapatan Asli Daerah Kota Surakarta Tahun 2005-2009" hasil penelitian terdapat kontribusi yang kuat antara retribusi jasa umum secara keseluruhan terhadap penerimaan Pendapatan Asli Daerah Surakarta tahun 2005-2009 diterima. Hal ini ditunjukkan dengan persentase perbandingannya secara berturut-turut yaitu $22,06 \%, 22,92 \%$, $24,56 \%, 28,83 \%$ dan $21,66 \%$. Terdapat tingkat efektivitas yang tinggi dari retribusi jasa umum secara keseluruhan di kota Surakarta tahun 2005-2009.

2. Boby Fandhi Putra (2014) yang berjudul Analisis Efektivitas Penerimaan dan Kontribusi Retribusi Daerah Terhadap Pendapatan Asli Daerah (Studi pada Dinas Pengelola Keuangan Daerah kota Blitar) hasil penelitian Tingkat efektivitas penerimaan retribusi daerah berdasarkan jenis-jenisnya selama periode 2008-2012 secara keseluruhan sudah efektif. Tetapi kontribusi retribusi daerah terhadap pendapatan asli daerah selama periode tersebut masih kurang, serta program intensifikasi dan ekstensifikasi yang dilakukan pemerintah belum optimal..

3. Mega Ersita (2016) dalam penelitiannya yang berjudul "Analisis Efektivitas Penerimaan Retribusi Daerah dan Kontribusinya Terhadap Peningkatan Pendapatan Asli Daerah (PAD) di Provinsi Sulawesi Utara hasil penelitian Tingkat efektivitas untuk retribusi daerah selama tahun 2011-2015 masuk dalam kategori Cukup efektif. Kontribusi 
retribusi daerah PAD Provinsi Sulawesi

Utara dari tahun 2011-2015 berkontribusi sedang tetapi rasio kontribusinya cenderung naik setiap tahunnya hanya pada tahun 2015 mengalami penurunan. Pimpinan Dinas Pendapatan Daerah Provinsi Sulawesi Utara sebaiknya terus mengoptimalkan pemungutan $\mathrm{PAD}$ dengan intensifikasi maupun ekstensifikasi, sehingga akan selalu ada perubahan dalam sistem penerimaan retribusi daerah kearah yang lebih baik.

\section{METODOLOGI PENELITIAN}

\subsection{DesainPenelitian}

Penelitian dilaksanakan di Kantor Kecamatan Ilir Barat Satu Kota Palembang. Penelitian ini menggunakan metode analisis deskriptif, dengan pendekatan kuantitatif yaitu rasio perbandingan efektivitas penerimaan retribusi daerah dan kontribusinya terhadap pendapatan asli daerah tahun 2015 sampai dengan tahun 2019. Menurut Kuncoro (2014:12) jenis penelitian deskriptif adalah jenis penelitian yang menggambarkan suatu fenomena suatu objek, suatu set kondisi, suatu sistem pemikiran, ataupun suatu kelas peristiwa. Untuk memahami konsep yaitu peraturan daerah kota Palembang Nomor 12 Tahun 2015, atau fenomena yaitu permasalahan yang terjadi berkaitan dengan pungutan retribusi izin pelayanan pemakaman di kota Palembang. Dalam hal penelitian ini terdiri dari dua variable yaitu variable bebas yakni retribusi izin pelayanan pemakaman (independen) dan variable terikat yakni pendapatan asli daerah (dependen).

\subsection{Jenis Penelitian}

Penelitian komparatif adalah peenelitian yang bersifat mmbndingkan. Pnelitian ini dilakukan untuk mmbandingkan persamaan dan peerbedaan dua atau lebih facta-facta dan sifat-sifat objek yang di teliti brdasarkan krangkaa pemmikiran tertentu. Pada penelitian ini variabelnya msih mandiri tetapi untuk sampel yang lebih dari satuu atau dlam waktuu yang berbeda.

\subsection{Teknik Pengumpulan Data}

Metode pengumpulan data yang digunakan peneliti dalam penelitian ini yaitu teknik dokumentasi dan studi pustaka. Menurut KBBI (Kamus Besar Bahasa Indonesia) dokumentasi adalah pengumpulan, pemilihan, pengolahan, dan penyimpanan informasi di bidang pengetahuan pemberian/ pengumpulan bukti dari keterangan seperti gambar, kutipan, guntingan koran, bahan referensi lain. Dimana dokumen-dokumen yang ada di Kecamatan Ilir Barat Satu kota Palembang serta di Dinas Perumahan Rakyat dan Kawasan Pemukiman (DPRKP) kota Palembang. Sedangkan studi pustaka diperoleh dengan mempelajari buku-buku mengenai kebijakan pemerintah, pajak/retribusi dan PAD, serta realisasi kontribusi retribusi terhadap pendapat asli daerah

\section{HASIL DAN PEMBAHASAN 4.1 Hasil Penelitian}

Penelitian ini merupakan penelitian yang bersifat deskriptif tentang kontribusi dari retribusi izin pelayanan pemakaman di wilayah Kecamatan Ilir Barat Satu terhadap pendapat asli daerah (PAD) kota Palembang. Untuk mendapat hasil penelitian yang diharapakan, peneliti menggunakan teknik dokumentasi.

Pada penelitian ini pembahasan akan dilakukan dengan menampilkan hasil dari teknik dokumentasi yang berupa dokumentasi (foto, gambar, bagan) penelitian akan dijelaskan pada bagian lampiran. 
Tabel 4

Standar operasional pelayanan administrasi pengurusan izin pelayanan di Kecamatan Ilir Barat Satu kota

Palembang

\begin{tabular}{|c|c|c|}
\hline No & Komponen & Uraian \\
\hline 1. & $\begin{array}{l}\text { Dasar } \\
\text { Hukum }\end{array}$ & 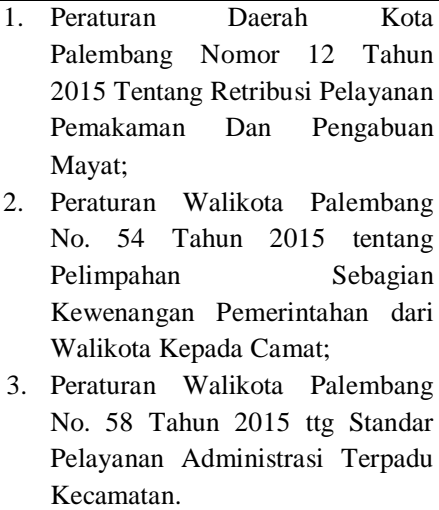 \\
\hline 2. & $\begin{array}{l}\text { Persyaratan } \\
\text { Pelayanan }\end{array}$ & $\begin{array}{l}\text { a. Surat Keterangan Laporan } \\
\text { kematian dari RT dan Kelurahan } \\
\text { setempat; } \\
\text { b. Surat keterangan Pemeriksaan } \\
\text { Jenazah dari Rumah Sakit atau } \\
\text { Puskesmas (mendiang yang } \\
\text { meninggal di RS); } \\
\text { c. Fotokopi Kartu Keluarga (KK) } \\
\text { Alm atau Almarhuma; } \\
\text { d. Fotokopi Kartu Tanda Penduduk } \\
\text { (KTP) Alm atau Almh; } \\
\text { e. Kalau sudah lengkap, ahli waris } \\
\text { dapat memesan tempatke TPU } \\
\text { yang diinginkan; } \\
\text { f. Surat Rekomendasi dari Dinas } \\
\text { Perumahan Rakyat dan Kawasan } \\
\text { Pemukiman (DPRKP) Kota } \\
\text { Palembang; } \\
\text { g. Membayar retribusi sesuai blok } \\
\text { tanah makam yang dikehendaki } \\
\text { dan ahli waris mendapat surat } \\
\text { IPTM (Izin Penggunaan Tanah } \\
\text { Makam) yang berlaku untuk } \\
\text { jangka waktu 3 (tiga) tahun. }\end{array}$ \\
\hline 3. & $\begin{array}{l}\text { Sistem, } \\
\text { mekanisme, } \\
\text { dan } \\
\text { prosedur }\end{array}$ & $\begin{array}{l}\text { 1. Pemohon mengisi formulir dan } \\
\text { melengkapi persyaratan; } \\
\text { 2. Petugas TPU menerima formulir } \\
\text { dan memeriksa persyaratan, } \\
\text { menentukan posisi letak } \\
\text { perpetakan tanah makam, } \\
\text { menerima uang titipan retribusi } \\
\text { per jenazah atau pemohon bisa } \\
\text { langsung ke kantor Camat; } \\
\text { 3endahara penerimaan menerima } \\
\text { uang titipan retribusi, membuat } \\
\text { daftar rekapitulasi setoran, } \\
\text { menyetorkan uang titipan retribusi } \\
\text { ke kas daerah \& SKRD dari } \\
\text { Kecamatan }\end{array}$ \\
\hline \multirow[t]{2}{*}{ No } & Komponen & Uraian \\
\hline & & $\begin{array}{llr}\text { 4. } & \text { Kabid pemakaman umum } \\
\text { mengeluarkan rekomendasi } \\
\text { penggalian/penggunaan tanah } \\
\text { makam; }\end{array}$ \\
\hline
\end{tabular}

\begin{tabular}{|c|c|c|}
\hline & & $\begin{array}{l}\text { 5. Petugas kecamatan menerima } \\
\text { rekomendasi/ penggunaan tanah } \\
\text { makam, mengeluarkan SKRD, } \\
\text { tanda tangan pejabat setempat dan } \\
\text { menyampaikan Surat Izin } \\
\text { Pemakaman kepada pemohon. }\end{array}$ \\
\hline 4. & $\begin{array}{l}\text { Jangka } \\
\text { waktu }\end{array}$ & Maksimal 5 (lima) hari kerja. \\
\hline 5. & Biaya/tarif & $\begin{array}{l}\text { Dapat dilihat pada peraturan daerah } \\
\text { kota Palembang Nomor } 12 \text { Tahun } \\
2015 \text {. }\end{array}$ \\
\hline 6. & Produk & 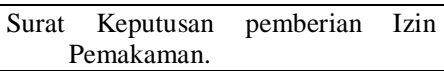 \\
\hline 7. & $\begin{array}{l}\text { Sarana, } \\
\text { prasarana, } \\
\text { dan/atau } \\
\text { fasilitas }\end{array}$ & $\begin{array}{l}\text { Sarana dan Prasarana: } \\
\text { a. Ruang tunggu yang representatif } \\
\text { dan dilengkapi AC; } \\
\text { b. Almari dokumen, rak arsip dan } \\
\text { alat tulis kantor; } \\
\text { c. Meja, kursi, dan pesawat telepon; } \\
\text { d. Komputer dan Printer; } \\
\text { e. Kotak saran; } \\
\text { f. Toilet umum. }\end{array}$ \\
\hline 8. & $\begin{array}{l}\text { Kompetensi } \\
\text { Pelaksana }\end{array}$ & $\begin{array}{l}\text { a. Kepala Kantor Camat Ilir Barat } \\
\text { Satu Kota Palembang; } \\
\text { b. Kepala Bidang Pelayanan; } \\
\text { c. Kepala Seksi Advice Planning } \\
\text { dan pendaftaran; } \\
\text { d. Kepala Seksi Verifikasi dan } \\
\text { Penerbitan izin; } \\
\text { e. Verifikator Dokumen Perizinan; } \\
\text { f. Petugas Routing Slip; } \\
\text { g. Petugas Penomoran; } \\
\text { h. Petugas Pengambilan Izin; } \\
\text { i. Pengadministrasi Pelayanan } \\
\text { Perizinan; } \\
\text { k. Costumer servise. }\end{array}$ \\
\hline 9. & $\begin{array}{l}\text { Pengawasan } \\
\text { internal }\end{array}$ & Dilakukan oleh atasan langsung. \\
\hline 10 . & $\begin{array}{l}\text { Penanganan } \\
\text { pengaduan, } \\
\text { saran, dan } \\
\text { masukan }\end{array}$ & $\begin{array}{l}\text { Sarana Pelayanan Pengaduan, Saran } \\
\text { dan Masukan: } \\
\text { 1. Unit Pelayanan Pengaduan Kantor } \\
\text { Camat Ilir Barat Satu } \\
\text { J1. Padang Selasa Kelurahan } \\
\text { Bukit Lama Palembang } \\
\text { Website } \\
\text { ilirbarat1 @ palembang.go.id } \\
\text { E-mail : } \\
\underline{\text { kecamatan.ilirbarat1 @ @mail.c }} \\
\text { om } \\
\text { Telepon : 0711-350572 / sms ke } \\
\text { 0857-58612365 } \\
\text { 2. Kotak saran/pengaduan. }\end{array}$ \\
\hline 11. & $\begin{array}{l}\text { Jumlah } \\
\text { pelaksana }\end{array}$ & $\begin{array}{l}\text { Jumlah personil yang menangani Izin } \\
\text { Pemakaman } \quad \text { (7) tujuh orang. } \\
\text { Keterangan: Setiap personil tersebut } \\
\text { di atas, juga melaksanakan } \\
\text { tugas pelayanan untuk jenis } \\
\text { izin yang lainnya. }\end{array}$ \\
\hline 12. & $\begin{array}{l}\text { Jaminan } \\
\text { pelayanan }\end{array}$ & $\begin{array}{l}\text { a. Diwujudkan dengan adanya } \\
\text { kepastian persyaratan, waktu } \\
\text { proses, biaya, prosedur, dan } \\
\text { didukung oleh SDM yang } \\
\text { berkompeten di bidang tugasnya }\end{array}$ \\
\hline No & Komponen & Uraian \\
\hline & & $\begin{array}{l}\text { b. Adanya jaminan bebas dari } \\
\text { praktek KKN. }\end{array}$ \\
\hline
\end{tabular}




\begin{tabular}{|c|c|c|}
\hline & & $\begin{array}{l}\text { Apabila izin jadi, pemohon akan } \\
\text { dihubungi melalui telepon. }\end{array}$ \\
\hline 13. & $\begin{array}{l}\text { Jaminan } \\
\text { keamanan }\end{array}$ & $\begin{array}{l}\text { Izin Pemakaman dibubuhi tanda } \\
\text { tangan asli dan dicap basah. }\end{array}$ \\
\hline 14. & $\begin{array}{l}\text { Evaluasi } \\
\text { kinerja } \\
\text { Pelaksana }\end{array}$ & $\begin{array}{ll}\text { 1. } & \text { Evaluasi kinerja dilakukan } \\
\text { melalui survey Indeks Kepuasan } \\
\text { Masyarakat (IKM) dengan } \\
\text { mekanisme, sebagai berikut: } \\
\text { a. Setiap pemohon izin yang } \\
\text { mengambil izin jadi akan } \\
\text { diberikan formulir IKM untuk } \\
\text { diisi. } \\
\text { b. Pengumpulan dan pengolahan } \\
\text { data. } \\
\text { c. Analisa data dan evaluasi. } \\
\text { d. Tindak lanjut hasil evaluasi. } \\
\text { Evaluasi berdasarkan pengawasan } \\
\text { atasan langsung terkait kinerja } \\
\text { kedisiplinan. }\end{array}$ \\
\hline 15. & $\begin{array}{ll}\text { Masa } & \\
& \text { Ber } \\
& \text { lak } \\
& \text { u } \\
& \text { Izin }\end{array}$ & 3 (tiga) tahun. \\
\hline 16. & $\begin{array}{l}\text { Waktu } \\
\text { Pelayanan }\end{array}$ & 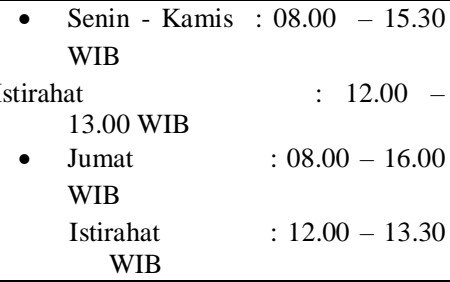 \\
\hline
\end{tabular}

Sumber : Data Kecamatan Ilir Barat Satu Kota Palembang, 2019

Tata cara dan pemungutan retribusi berdasarkan Peraturan Daerah Kota Palembang Nomor 12 Tahun 2015 tata cara dan wilayah pemungutan retribusi, yaitu:

1. Retribusi dipungut dengan menggunakan SKRD (Surat Ketetapan Retribusi Daerah) yang diterbitkan oleh sistem administrasi pelayanan perizinan terpadu satu pintu yang dikelola oleh Kecamatan Ilir Barat Satu Palembang;

2. Hasil pungutan retribusi disetor ke kas umum daerah paling lama 1 hari kerja;

3. Dalam hal wajib retribusi tidak membayar tepat pada waktunya atau kurang membayar, dikenakan sanksi administrasi berupa bunga sebesar $2 \%$ (dua persen) setiap bulan dari dari retribusi yang terutang yang tidak atau kurang bayar dan ditagih dengan mengunakan SKRD.

\subsection{Pembahasan}

Besarnya pendapatan asli daerah digunakan untuk menentukan tingkat kemandirian suatu daerah, semakin besar sumbangan pendapatan asli daerah suatu daerah maka semakin mengurangi ketergantungan pemerintah daerah terhadap bantuan dari pemerintah pusat. Salah satu dari pendapatan asli daerah yaitu retribusi izin pelayanan pemakaman. Di kantor Kecamatan Ilir Barat Satu membawahi 6 (enam) kelurahan yaitu terdiri dari Kelurahan Bukit Lama, Kelurahan Bukit Baru, Kelurahan Demang Lebar Daun, Kelurahan Siring Agung, Kelurahan Lorok Pakjo dan Kelurahan 26 Ilir D-1.

Taman pemakaman umum (TPU) yang berada di wilayah Kecamatan Ilir Barat Satu sendiri cukup banyak yang dimiliki masyarakat, swasta dan pemerintahan. Tetapi dari sekian banyak pemakaman yang tersebar hanya dua yang dikelola oleh pemerintah kota Palembang yaitu :

1. TPU puncak sekuning yang ada di Kelurahan Lorok Pakjo;

2. TPU bukit lama yang ada di Kelurahan Bukit Lama.

Dilihat dari lokasi TPU tersebut mayoritas warga menganut agama islam, maka kebanyakan warga hanya melakukan 2 (dua) jenis pemberkasan izin pemakaman yaitu izin pemakaman baru untuk masa berlaku 3 (tiga) tahun dan izin perpanjangan pemakaman setelah masa berlaku habis.

\section{KESIMPULAN}

Dari hasil penelitian dapat disimpulkan bahwa :

1. Sumber daya manusia dalam pelaksanaan pelayanan perizinan pemakaman memiliki kualitas dan kinerja yang baik hal ini dapat dilihat dari kontribusi retribusi yang dihasilkan dimana pegawai mampu memberikan pelayanan secara cepat, efektif, dan maksimal walaupun masih banyak keterbatasan. Produktivitas penerbitan 
izin pemakaman di Kecamatan Ilir Barat Satu dapat dikatakan belum maksimal karena masih adanya keluhan masyarakat yang kurang mendapat informasi mengenai retribusi izin pelayanan pemakaman.

2. Penerimaan retribusi izin pelayanan pemakaman di Kecamatan Ilir Barat Satu dari tahun 2015 sampai tahun 2019 mengalami peningkatan. Artinya retribusi daerah sudah memberikan kontribusi yang cukup besar terhadap pendapatan asli daerah. Nilai kontribusi penerimaan retribusi izin pelayanan pemakaman menunjukkan adanya kecenderungan berfluktuasi tiap tahunnya presentase rata-rata kontribusi penerimaan retribusi izin pelayanan pemakaman dengan kriteria cukup baik mencapai $20,17 \%$. Berdasarkan kondisi tersebut jelas terlihat bahwa standar administrasi pelayanan yang belum maksimal.

\section{SARAN}

Berdasarkan uraian dari kesimpulan di atas maka penulis dapat memberikan saran antara lain, yaitu :

1. Diharapkan para pegawai dapat memberikan pelayanan yang prima dalam meningkatkan kualitas pelayanan administrasi terpadu kecamatan (PATEN), yang wewenangnya telah dilimpahkan pada Kecamatan Ilir Barat Satu. Sosialisasi dari pemerintah daerah dalam memberikan informasi dan pemahaman tentang retribusi maupun sumber Pendapatan Asli Daerah demi kesejahteraan masyarakat dan peningkatan pembangunan daerah agar kepuasan masyarakat selalu terjaga dan terjalin kerja sama yang baik antara masyarakat dan pemerintah sehingga dapat meningkatkan kepercayaan publik;

2. Diharapakan Kecamatan Ilir Barat Satu dapat memperbaiki dan menambah sarana dan prasarana izin pelayanan

pemakaman serta mengoptimalkan
pemungutan retribusi dengan
intensifikasi maupun ekstensifikasi
sehingga penerimaan retribusi dapat
berjalan dengan signifikan untuk
menunjang pendapatan asli daerah
(PAD) kota Palembang.

VII. DAFTAR PUSTAKA

[1] Akuntansi Keuangan Daerah, UPP AMP YKPN, Yogyakarta, Halim, Abdul, 2001.

[2] Akuntansi Keuangan Lanjutan 1, Edisi Ke 2 Buku 1, Salemba Empat, Richard, 2015.

[3] Akuntansi Keuangan Lanjutan 1, Edisi Ke 2 Buku 2, Salemba Empat, Richard, 2016.

[4] Kamus Bahasa Indonesia, Edisi III, E, Jakarta, Balai Pustaka, 2008.

[5] Kebijakan Pelayanan Administrasi Terpadu Kecamatan, Dian Utomo, Jakarta, Cetakan Pertama, 2010.

[6] Makro Ekonomi, Edisi Ke 21, PT Raja Grafindo Persada, Sukirno, 2010.

[7] Manajemen Administrasi Perkantoran,Kasnisius, Yogyakarta, Nuraini Ida, 2008.

[8] Membangun Kinerja Pelayanan Publik, Pustaka Setia,Zaenal Mukarom, 2016.

[9] Metode Riset Untuk Bisnis dan Ekonomi, Erlangga, Jakarta, Mudrajat, ,2014.

[10] Metode Penelitian Kuanititatif Kualitatif, Alfabeta Sugiyono, 
Bandung, 2010.

[11] Metode Riset Akuntansi Pendekatan Kuantitatif, Cetakan Ke 2, Salemba Empat, Jakarta, Chandrarin, 2017.

[12] Pajak Daerah dan Retribusi Daerah, Edisi Revisi, Jakarta, Siahaan, Marihot P, 2005.

[13] Pengantar Sosiologi, Edisi Revisi, Jakarta, PT Raja Grafindo Persada, Soekanto, Soejono, 2008.

[14] Perpajakan, Edisi Revisi, Yogyakarta, Andi Ofset, 2002.

[15] Penyusunan dan Analisisis Laporan Keuangan Pemerintah Daerah, Edisi Pertama, Edy P Gege, 2010.

[16] Perpajakan Indonesia, Edisi Pertama, Penerbit Balai Pustaka, Boediono, 2001.

[17] Reformasi Pelayanan Publik Teori, PT Bumi Aksara, Sinambela, 2011.

[18] Teori Akuntansi, Cetakan Keempat Belas, Edisi Revisi, Jakarta,ISBN:978-979-76-9091, Harahap Sofyan S, 2011.

[19] Teori dan Proses Kebijakan Publik, Edisi Pertama, Penerbit Balai Pustaka, Winarno, 2010. 